\title{
New Christians, Converted Hindus, Jesuits, and the Inquisition
}

\author{
José Eduardo Franco \\ Open University of Portugal, Department of Social Sciences and \\ Management, Lisbon, Portugal \\ eduardofranco.cidh@gmail.com
}

Célia Tavares

State University of Rio de Janeiro, Department of Human Sciences, Rio de Janeiro, Brazil celiatavares@uol.com.br

\begin{abstract}
This paper analyses the complex relationship between Jesuits, New Christians, converted Hindus, and the Inquisition. The collaboration of Jesuits with the Holy Office did not prevent voices from being raised within the Society of Jesus against the tribunal's practices, which were observed with caution by the first Jesuit leaders. For their part, conversos were initially welcomed into the Society and even assumed high positions in the Society, such as the second superior general. Despite the difficult history of intolerance and inquisitorial persecution against New Christians, in the seventeenth century, Jesuits in Portugal became prominent advocates of their cause. In turn, Hindu conversion strategies fueled disputes and tensions between the Society of Jesus and the Inquisition of Goa. Their strained relations make these disputes an important historiographical subject for understanding many of the plots and dramas of Portuguese society under the Old Regime.
\end{abstract}

\section{Keywords}

Inquisition - conversos - Hindus - Jesuits - Portugal - Goa 


\section{Preliminary Considerations}

When studying the tense relations that existed between two institutions within the Catholic Church - the Inquisition and the Society of Jesus - one should bear in mind that the latter was established while coming under fire from the former. The spiritual and intellectual trajectory of the founders of the Jesuits was beset by various intimations, arrests, and reproaches by the Inquisition in the cities where Ignatius of Loyola $(c .1491-1556)$ and his companions-who hailed from Spain, France, or the Italian peninsula-travelled, resided, and studied. $^{1}$

At a time when the Inquisition was reinforcing its surveillance and fomenting an atmosphere of widespread suspicion, the author of the Spiritual Exercises and his followers were repeatedly stigmatized as contaminated by the notions of Erasmus of Rotterdam (1469-1536)or alumbradismo that threatened the guardians of Catholic orthodoxy at the time. ${ }^{2}$

Notwithstanding the harsh treatment that the nascent Society of Jesus received at the hands of the Inquisition, the contemporary outlook and power politics from whose grasp the Jesuits were not spared, as well as their unwillingness to endanger the adoption of their philosophy within Catholic societies, induced Jesuits to collaborate with the Inquisition - an institution that increasingly became the dominant force in the regulation of social relations, the standardization of experiences and religious and cultural expressions, and the domestication of customs and mentality. In an ideologically uncompromising study, the Jesuit historian John W. O'Malley documented this indelible complicity, noting that Ignatius himself offered his support to King João III $(1502-57 ;$ r.1521-57) in order to pave the way for the papal approval that would allow the definitive establishment of the Inquisition Tribunal in Portugal. ${ }^{3}$ The papal bull Cum ad nihil magis had already established the tribunal in 1536, but it needed to wait until the end of the 1540 os for the pope's definitive approval.

As to the kingdom of Portugal's commitment to establish the Inquisition, lay Portuguese experts, such as Luís Reis Torgal, place the emphasis on economic motivations. ${ }^{4}$ Francisco Bethencourt, an expert on the Inquisition in

Ludwig Marcuse, Soldier of the Church: A life of Ignatius Loyola (London: Ulan Press, 2012), 287 .

2 Cándido de Dalmases, Ignace de Loyola: Le fondateur des jésuites (Paris: Le centurion, 1984), 40; Mark Rotsaert, Ignace de Loyola et les renouveaux spirituels en Castille au début du XVIème siècle (Rome: Centrum Ignatianum Spiritualitatis, 1982), 15.

3 John W. O'Malley, The First Jesuits (Cambridge, MA: University Harvard Press, 1995), 310-20.

4 Luís Reis Torgal, “A Inquisição: Aparelho repressivo e ideológico do Estado," Revista Biblos 51 (1975): 631-48, here 637 . 
Portugal, offers a more sophisticated argument by singling out the reasons that led to the establishment of the Holy Office in Portugal, but attributes the basis of these motives to a strategy of state control. ${ }^{5}$

Admittedly, Ignatius of Loyola provided an important service to Rome in terms of Portuguese diplomacy by ending the prolonged delay in the negotiations for the final confirmation of the Portuguese Inquisition by the Roman Curia with the publication of the bull Meditatio cordis on July 16, 1547. ${ }^{6}$ It is also true, however, that the Society's first superior general had reservations about King João III's insistence that the Jesuits be nominated inquisitors in Portugal. Nonetheless, the provincial of the Portuguese Jesuits, Diogo Mirão (1516-9o), of Spanish origin, effusively welcomed the king's proposal; he understood that this position would improve the Society's prestige, particularly in light of the negative social image of the New Christians, with whom the Jesuits were associated. The Society's control over the Inquisition tribunals, he reckoned, would help the order to avoid in Portugal the kind of persecution to which it had been subjected in Spain. ${ }^{7}$

The New Christians in Portugal had long suffered from a bad reputation, but the situation took a turn for the worse with the arrival of the Inquisition in the sixteenth century. Anti-Semitic propaganda succeeded in cultivating intense anti-Jewish sentiment and popularized perniciously potent myths concerning the "Hebrew race." 8 As was the case with anti-Jesuitism, anti-Judaism fabricated and exaggerated information to vilify its victims.

Although the evaluation committee nominated by Ignatius of Loyola in Rome responded positively to the Portuguese king's proposal, the founder

5 Francisco Bethencourt, "A Inquisição," in História religiosa de Portugal, ed. Carlos Moreira Azevedo, 3 vols. (Lisbon: Círculo de Leitores, 200o), 2:99. See the comparative work from the same author that has become essential for the study of this tribunal: Francisco Bethencourt, The Inquisition: A Global History, 1478-1834 (Cambridge: Cambridge University Press, 2009). See also the relevant studies by Maria José Ferro Tavares, Judaísmo e Inquisição: Estudos (Lisbon: Presença, 1987). More recently, see José Pedro Paiva and Giuseppe Marcocci, História da Inquisição em Portugal, 1536-1821 (Lisbon: Esfera dos Livros, 2013).

6 Ignatius of Loyola, Monumenta ignatiana ex autographis vel ex antiquioribus exemplis collecta. Series prima: Sancti Ignatii de Loyola Societatis Jesu fundatoris epistolae et instructiones, 12 vols. (Madrid: Typis Gabrielis López del Horno, 1904), 2:269 ff. Together with this bull, which definitively established the Inquisition in Portugal, a powerful instrument for prosecution was established with a provision for witness protection for those who made accusations, prohibiting the defendants from knowing who their accusers were. Bethencourt, "Inquisição," 2:95-131.

7 Francisco Rodrigues, História da Companhia de Jesus na Assistência de Portugal, 4 vols. (Porto: Apostolado da Imprensa, 1931), 1:252, 692.

8 Archivio Segreto Vaticano (ASv), Nunziatura-Portogallo, "Cartas de Évora," March 10 and April 16, 1575, vol. 2, fol. $35^{\mathrm{v}}$. 
of the Jesuits made his reservations about such a proposition known; so as not to displease the king, he submitted the decision to the pope. To breach this impasse, the king eventually appointed the Dominican Friar Jerónimo de Azambuja (?-1563) as inquisitor for the Tribunal of Lisbon, because Cardinal D. Henrique (1512-80) himself did not favor the appointment of a member of the Society of Jesus for the position.

A second proposal — that Jesuits would fill important inquisitorial positions in the Holy Office in the context of the expansion of this institution to other cities, particularly in connection with the project of establishing a similar tribunal in Coimbra-was rejected outright by Ignatius of Loyola. He justified his refusal by stating that the immunities granted to inquisitors, namely, the dismissal of the vow of obedience to the superiors of the order, were incompatible with the special religious status of the Jesuits. Later, the superior general of the Society of Jesus, Diego Laínez (1512-65; in office 1558-65), urged the Jesuits not to become part of the Inquisition, and the visitor in the East, Alessandro Valignano (1539-16o6), included this injunction in the rules that he wrote in $1588 .{ }^{9}$

Despite these authoritative exhortations, Jesuits often delivered sermons as well as served as verifiers (qualificadores), inspectors (conducting visits to ships), commissioners, deputies, and even prosecutors on behalf of the Holy Office in Goa, alongside members of other religious orders established in Portuguese India. ${ }^{10}$ In this regard, we may mention that from a total of seventy-six members and promoters of the Goa Inquisition until 1682, sixty-one belonged to religious orders - twenty Dominicans; seventeen Jesuits; eleven Augustinians; ten Franciscans; and three from other orders-while the other fifteen were employees of the tribunals and other offices of the king (nine) and the secular clergy (six). ${ }^{11}$ Portugal's inquisitorial tribunals did not follow this trend from Goa. It is true that representatives of the Society of Jesus held positions such as verifiers, inspectors, and commissioners in addition to preachers at autos-da-fé, but we also find only a few of them among inquisitorial deputies and prosecutors.

9 See "Sumário das regras para o provincial da Índia," in Documenta Indica, 18 vols., ed. Joseph Wicki (Rome: Monumenta Historica Societatis Iesu, 1965), 14:85o.

10 According to António Baião, when the Inquisition was established, the notaries themselves provided the reports, with deputies also assuming the role of prosecutors. Thus, there was no distinction between these functions in India. António Baião, A Inquisição de Goa: Tentativa de história da sua origem, estabelecimento, evolução e extinção; Introdução à correspondência dos Inquisidores da Índia 1569-1630, 2 vols. (Lisbon: Academia das Ciências, 1945), 1:178. 
Bethencourt has argued that "there is a large number of appointments of men religious from the Society of Jesus to the position of verifiers," although he does not provide figures. ${ }^{12}$ Despite the lack of quantification, however, we can assume the validity of this statement, as it resonates with the many references to these roles found in biographies of the Jesuits.

Consulting the existing lists in the Inquisition archives at Torre do Tombo, we see an intriguing trend. In the case of the Inquisition of Coimbra, for example, in the period from its creation until 1732 , in a total of 260 records that refer to the names of the deputies, only twelve are identified as regular clerics; the vast majority of employees are secular priests. Among those who are regulars, we find no Jesuits among seven Dominicans, three Augustinians, one Franciscan, and one Benedictine. ${ }^{13}$

In the General Council of Portugal's Holy Office, there are ninety-two records that reference ministers up to 1705 . Again, most of the ministers are from the secular clergy, while only thirteen are members of the regular clergy: eleven Dominicans, one Augustinian, and one Jesuit, Father Jorge Serrão (c.1528-9o), who was appointed in $1579 .{ }^{14}$

The same pattern emerges in the Inquisition of Évora. Information gleaned from a total of 117 records discloses that in the period up to 1730, there were only seventeen regular clerics: thirteen Dominicans, three Franciscans, and one Jesuit—Manuel do Valle (c.1564-1650), who was appointed around $1603 \cdot{ }^{15}$

In his História da Companhia de Jesus na assistência de Portugal (History of the Society of Jesus in the assistance of Portugal), Francisco Rodrigues aimed to show that the contribution of members of the order was limited to tasks of spiritual edification, largely preaching and admonishing those prisoners convicted by the Inquisition in order to move them to repent and thus avoid capital punishment.

Highlighting the kerygmatic and spiritual role of the Society's priests in the auto-da-fé, which was confined to "softening" the conviction and sparing the condemned from the extreme penalties to which they were sentenced, this Jesuit historian argued that the Society cooperated no further with the Inquisition. ${ }^{16}$

12 Bethencourt, "Inquisição," 114.

13 Arquivos Nacionais Torre do Tombo (ANTT), Inquisição, Conselho Geral, liv. 258, fols. 7-19v.

14 ANTT, Inquisição, Conselho Geral, liv. 258, fols, $125^{-} 33^{\mathrm{v}}$.

15 ANTT, Inquisição, Conselho Geral, liv. 258, fols. 155-62.

16 Rodrigues, História da Companhia de Jesus, 1:692-93. 


\section{Participation of Jesuits in Inquisitorial Activities}

Without casting aspersions on the charitable and spiritual inclination of Jesuit preachers in the horrifying scenario of the public execution of death sentences issued by the Holy Office, we cannot deny that, as demonstrated by the data presented, some members of the order did play an active role in assisting in the implementation, expansion, and consolidation of the Portuguese Inquisition in the sixteenth century, especially in the case of the Tribunal of Goa. In addition to the aforementioned participation of Ignatius of Loyola, Francis Xavier (1506-52) himself also played an influential role in apprising King João III about the importance of creating an inquisition in Goa. In May 1546, he wrote to the king, lamenting the lack of preachers in India: "Because of their scarcity $[\ldots]$ there is a lack of Faith among us, the Portuguese." He then made a recommendation that would help to prevent the contamination of faith and fight the infidels and paganism in the colony:

The second need that India has in order to have good Christians is that Your Highness send an Inquisition because many live under the Mosaic Law and the Moorish sect, with no fear of God nor shame of the world. And because these are many and live scattered in all the garrisons, we need the Inquisition and many preachers. ${ }^{17}$

We understand that this opinion was in line with the dominant church mentality of the time, especially in Iberian Christendom, which saw the Inquisition as an indispensable tool for ensuring the purity of faith and morals.

The Portuguese Inquisition arrived in Goa only after the death of King João III, following the decision of Cardinal Henrique on March 20, 156o during the regency of Queen Catarina (r.1557-62). ${ }^{18}$ Eventually, in Goa, many Jesuit priests came to provide regular services to the Inquisition, ${ }^{19}$ either as preachers or as tribunal deputies. ${ }^{20}$

17 Georg Schurhammer and Josef Wicki, eds., Epistolae S. Francisci Xavierii, 2 vols. (Rome: Monumenta Historica Societatis Iesu, 1944), 1:346-47.

18 Raul Rêgo, $O$ último regimento e o regimento da economia da Inquisição de Goa (Lisbon: Biblioteca de Nacional, 1983), 10.

19 According to the data gathered by António Baião, between 1760 and 1718, twenty percent of the deputies who participated in the Inquisition of Goa were Jesuits, although this does not mean that all Jesuits favored participating in the Inquisition or agreed with its methods. António Baião, ed., A Inquisição de Goa: Correspondência dos inquisidores da Índia 1500-1630 (Coimbra: Imprensa da Universidade, 1930), chapter 3.

For statistical research and sociological analysis of preachers and individuals who held institutional positions. In studying the issue of cooperation, consider also some inquisitorial 
Another significant impact that the Society had on the Inquisition was delivered via the advice given by the Jesuit Leão Henriques (1524-89) to Cardinal Henrique, while the latter was preparing the first statute (Regimento) of the Holy Office, which was completed in $155^{2 .{ }^{21}}$ The text was diligently prepared, and reveals an awareness of the importance of mitigating, if not eliminating, overlap between the spheres of temporal and spiritual power. This Regimento is a legal text characterized by markedly ecclesiastical features. Its regulations provide a legal framework that emphasizes the subordination of this tribunal to the Roman pontiff in order to reduce the elements of state ownership that had plagued the tribunal since its establishment in Portugal. ${ }^{22}$

While the inquisitor-general acknowledged the tribunal's dependence on the Portuguese monarch in the Regimento's prologue, as it turned out, Cardinal Henrique's long-lasting leadership of the tribunal resulted in an accentuation of its independence, betraying the fact that the manipulation of the Inquisition "by political strategy did not provide the desired results." As Bethencourt concluded,

If the inquisitorial bureaucracy assumed a decisive position within the Church in Portugal, with many new bishops coming from its ranks, especially in the sixteenth and seventeenth centuries, the Holy Office turned out to be much more independent than D. Manuel and D. João III (the initiators of the project) desired, causing problems to the royal policy in the long run. Indeed, this policy towards the Inquisition or the diversity of religious sensibilities went through changes depending on the monarchs and orientation of the power groupings. ${ }^{23}$

Indeed, the figure of Leão Henriques was so revered that Sebastião Gonçalves $\left(1557^{-1619)}\right.$, a Jesuit who wrote a history on the Society of Jesus in the East in

statements in the East, which were less favorable to the Society of Jesus in the context of the controversies surrounding the missionary methods that the Jesuits adopted in the evangelization process of Malabar, Japan, and China. See José Lourenço de Mendonça and António Joaquim Moreira, História dos principais actos e procedimentos da Inquisição em Portugal (Lisbon: Imprensa Nacional-Casa da Moeda, 1980), $144 \mathrm{ff}$.

21 We should also bear in mind that the provincial of the Jesuits, Jorge Serrão, and also the lesser-known Manuel Alvares Tavares (1526-83), both held the position of deputy of the Inquisition of Évora and Coimbra. See Herman P. Salomon, Portrait of a New Christian: Fernão Alvares Melo, 1569-1632 (Paris: Fundação Calouste Gulbenkian, 1982), 73, 111-12.

22 José Eduardo Franco and Paulo de Assunção, Metamorfoses de um polvo: Religião e política nos regimentos da Inquisição, sécs. XVI a XVIII (Lisbon: Prefácio, 2004), 16.

23 Bethencourt, "Inquisição," 99. 
the early seventeenth century, depicted him as an inquisitor, as can be seen in the following excerpt:

Inquisitors always had companions, so usually we have two inquisitors, who in turn have deputies often from different religious orders. There were often two from the Society; from the same Religion the Inquisitors choose learned men to preach in the scaffolds. Father António de Quadros [c.1529-72], our provincial, preached sometimes; Provincial Father Ruy Vicente [1523-87], Visitor Father Nicolau Pimenta [1546-1613], Father Pero Francisco [c.1565-1615], and Father Dr. Antonio Fernández [1568-1642]. The Holy Office has a prosecutor, a bailiff, secretaries, guards, a gatekeeper, and familiars. The rector of the College of São Paulo kept the records. Outside Goa, the Society's priests were usually the commissioners of the Holy Office. And just as Saint Peter [of Verona] of the Order of Preachers [1206-52] suffered martyrdom for being an inquisitor, also Father António de Quadros would have been killed by the doctor who was curing him if the Abyssinian apothecary did not know about the plot to kill him; and Father Belchior da Fonseca [c.1554-16o3], a commissioner in Bengal, died of poison given to him for doing his work. In Portugal, Leão Henriques was one of the great head inquisitors, succeeded by Father Jorge Serrão, and both of them were provincials. ${ }^{24}$

This description is puzzling, because we know that Henriques was not an inquisitor, nor was the other Jesuit mentioned, Jorge Serrão. Rather, both participated as ministers of the General Council, as previously mentioned. Apparently, Sebastião Gonçalves was not loath to link the Society of Jesus to the Inquisition, even if it meant exaggerating the performance of some of his companions. However, Henriques was not an inquisitor, nor was Serrão, and even the former never accepted the privileges and honors that were attached to the position as member of the General Council. ${ }^{25}$ In addition, this excerpt illustrates the lack of uniformity of opinion among Jesuits as to what their relationship with the inquisitorial tribunal should be. Jesuits were called upon several times to collaborate as experts in doctrinal matters as qualifiers of the Holy Office. The qualifier was charged with the task of "providing opinions

24 Sebastião Gonçalves, Primeira parte da história dos religiosos da Companhia de Jesus..., 3 vols. (Coimbra: Atlântida, 196o), 2:321-22.

25 Charles E. O'Neill and Joaquín Dominguez, eds., Diccionario histórico de la Compañía de Jesús: Biográfico-temático, 4 vols. (Madrid: Universidad Pontificia Comillas, 2001), 2:899-90o. 
on seized books or on prisoner's statements and on the content of reports."26 Such technical evaluations carried significant weight in the determination of judicial decisions.

The appointment of Jesuits to several inquisitorial positions did not necessarily mean that the order wholeheartedly and unanimously identified with the Inquisition or consented to maintaining long-lasting relations and coordination of objectives with it. Nor does it signify that Jesuits, as a rule, pursued inquisitorial offices with alacrity. On the contrary, we often sense reluctance in their resigned acceptance to work in the tribunals of the Inquisition. Other religious orders, by contrast, such as the Dominicans, built a more prominent tradition within the Portuguese Inquisition, apparent from the number and quality of positions that they held in this institution. Besides Ignatius's apparent lack of enthusiasm for Society members' assumption of positions in the Holy Office, there are several other examples of Jesuits hesitating to accept these positions, in line with the spirit of their founder.

The visitor of the Society of Jesus in the East, Valignano, deemed it imprudent for the Jesuits to be part of the inquisitorial hierarchy, although it was natural that some of them, due to their theological and juridical knowledge, would be called on to share that knowledge for the benefit of the judicial proceedings of the Holy Office. ${ }^{27}$ His opinion arises out of sophisticated strategy, at once drawing on the Society of Jesus's constitutional priorities and mindful of their social image. Thus, both Ignatius and Valignano knew very well that the Inquisition was not a socially friendly institution, and easily created antagonisms. A close involvement of the Jesuits in the inquisitorial hierarchy and in its surveillance and punishment activity would inevitably harm the reputation of the Society of Jesus.

As they expounded in their discourses, the most highly regarded Jesuit leaders tended to view collaboration with the Holy Office as a service that lay outside the purview of their order and even violated its guiding principles. There were cases where these tasks were imposed on the Jesuits despite their disagreement. A paradigmatic example of this unwanted imposition was the case of Manuel de Sá (1658-1728), who arrived in Goa in 1711 from Portugal to work in the Indian missions of the Society. He was immediately informed that he had been nominated deputy of the local tribunal of the Inquisition. Despite his protests, in which he claimed that the position was incompatible with the guidelines of the Society of Jesus and the pope, he was forced by the

26 O’Neill and Domínguez, Diccionario, 1:114.

27 Alessandro Valignano, "Sumário das normas para a Província da Índia, abril de 1588," in Documenta Indica, 14:849-50. 
inquisitor general to accept. A year later, one of his colleagues, José Pereira (dates unknown), was nominated to the same position. Pereira replied with the same objections, now backed by the support of the provincial of the Jesuits of Goa. But even the mere rejection of these functions was deemed a serious act of insubordination by the Inquisition; the grand inquisitor countered that he held a power delegated to him by the Roman pontiff to make this nomination, and thus disobeying him was equivalent to disobeying the pope. $^{28}$

The friction between the Society and the Inquisition notwithstanding, we will argue that the relationship between them was maintained without major disturbance and even with complicity and cooperation, apart from some disagreements, especially in the period dating from the implementation of the Society of Jesus in Portugal until the proclamation of the House of Braganza's dynastical restoration or independence from the Spanish Habsburgs in $1640 .{ }^{29}$ There was, however, an atmosphere of discord that persisted in the background, especially during the last few years of the Habsburg regime in Portugal, due to the support that some Jesuits provided to the New Christians and the unfavorable assessments some Jesuit priests made of the Inquisition's methods. For example, in 163o, during a visit by the new general inquisitor, D. Francisco de Castro (1574-1653) to the Portuguese inquisitions, the documented complaints of Father Gaspar Miranda (1564-1639), who resided in the College of the Holy Spirit in Évora, were presented. The documents constituted a "terrible accusation" against the judicial practice of the Inquisition. It denounced the cruelty of inquisitorial torture in the prisons and the inhumane treatment of prisoners' families, especially children, that left them destitute and without means of sustenance. Thus, when New Christians were accused and arrested, their possessions were immediately confiscated. ${ }^{30}$ In the following section, we will discuss these disagreements between the Society of Jesus and the Portuguese Inquisition and explore their consequences.

28 Archivum Romanum Societatis Iesu (ARSI), Goa 9, II, fols. $529^{\mathrm{r}}-53^{\mathrm{r}}, 546^{\mathrm{r}}-55^{\mathrm{r}}$; 36 , II, fol. $310^{\mathrm{r}}$.

29 There were even some recorded occasions when the Inquisition acted in favor of the Society of Jesus when its opponents vilified it. For example, in 1615, the Inquisition ordered the seizure and a full inquiry of an anti-Jesuit paper entitled "Razões que o Dr. João Bravo Chamiso, lente de Anatomia d'esta universidade e vereador do corpo d'ela fez sobre os Padres da Companhia," which was attributed to a professor of anatomy from the University of Coimbra. See ANTT, Inquisição de Coimbra, processo no. 1427, fol. $148^{\mathrm{r}}$.

30 António Borges Coelho, Inquisição de Évora, 1533 a 1668, 2 vols. (Lisbon: Caminho, 1987), 2:209-34. 


\section{Conflicts between the Jesuits and the Inquisition in the Seventeenth Century}

As previously mentioned, the Society of Jesus and the Inquisition in Portugal maintained a relatively peaceful coexistence until 1640. However, the same cannot be said concerning the Portuguese domains in Asia. In addition to the debate involving the New Christian denizens of European origin, apparent in the abovementioned recommendation made by Xavier for the establishment of the Inquisition in Goa, a new tension arose in Asia. The controversial methods of mass conversion adopted by the Jesuits on the west coast of India had yielded a bumper crop of fresh Christians among the locals, prompting inquisitorial action in the region and friction with the Society of Jesus. The controversy between the Society of Jesus and the Goa Inquisition intensified when the Jesuits' methods of conversion were altered in order to attract the most important portion of Indian society-the Brahmins-in areas close to Portuguese rule in India. A good example of this rift is the story surrounding João Delgado Figueira (c.1585-1654), who was the prosecutor of the Holy Office in the city of Goa at the time, and from 1626 , served as one of its inquisitors.

The story concerns the debate about certain pagan rites defended by the Tuscan Jesuit Roberto de Nobili $(1577-1656)$ as external practices harmless to the Catholic faith. ${ }^{31}$ This discussion began in 1610; in 1618, Pope Paul V (1550$1621 ;$ r.1605-21) ordered the archbishop and the inquisitors of Goa to gather and analyze the practices of Nobili in Malabar. On January 31, 1619, a committee was established, formed by the archbishops of Goa (Cristóvão de Sá e Lisboa [c.1568-1622], from the order of Saint Jerome) and of Cranganor (the Jesuit Francisco Rodrigues [1599-1624]), along with the Inquisition prosecutor João Delgado Figueira (156o-1623). The purpose of the committee was to gather "sufficient information to know if the rites of the Brahmins and the line, the sikha, the sandalwood, and the practice of ritual ablutions were signs of the false sect of idols." 32 The archbishop of Cranganor presented to the committee a "long treatise" on the nature of the "heathen" rites and recommended that it

31 Concerning the rites controversies in India, see Ines G. Županov and Pierre Antoine Fabre, eds., The Rites Controversies in the Early Modern World (Leiden: Brill, 2018); Adone Agnolin, $O$ amplexo político dos costumes de um jesuíta brâmane na Índia: A acomodação de Roberto de Nobili em Madurai e a polêmica e a polêmica do Malabar; Século XVII (São Paulo: USP, 2017); Paolo Aranha, Il cristianesimo latino in India nel XVI secolo (Milan: Franco Angeli, 2006); Sabina Pavone, "Riti malabarici," in Dizionario storico dell'Inquisizione, ed. Adriano Prosperi et al., 4 vols. (Pisa: Edizioni della Normale, 2010), 3:1327-29.

32 ANTt, Conselho Geral do Santo Ofício, liv. 207. Consultas da Inquisição de Goa (1572-1620),

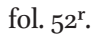


be read by theologians. There were also original books brought from Madurai, but only the archbishop of Cranganor and Nobili knew how to read them. The archbishop of Goa asked them to explain the content of these books. The Jesuit was the first to speak, endorsing the merely "political character" of these rites. ${ }^{33}$ On February 9, 1619, the archbishop of Cranganor sent a letter to the committee, in which he declared that he and the priests of the Society of Jesus, "considering the experience of many years and the knowledge of the books and languages of the Brahmans," were familiar with the line, the sandalwood, and the ritual ablutions, and recognized them as indications of the nobility of Brahmin families. Thus, he corroborated Nobili's position. ${ }^{34}$

However, there were others who disagreed. For example, a letter to the committee from the bishop of Cochin, the Augustinian Sebastião de São Pedro (1582-1629), dated June 6, 1619, employed the same assertion of knowledge based on personal experience to make the opposite argument. In his letter, the bishop denounced the rites in the strongest terms, saying that "I came to India thirty-five years and six months ago [...] and in my experience of these regions [...] I know that the line is a demonstrative sign of heathenry and of a false religion that the Brahmins profess." ${ }^{35}$ On the basis of this claim, the Inquisition prosecutor Figueira organized his argument by listing the questions sent by the pope and then answering with arguments both for and against these rites. He analyzed the issue from two perspectives: the legality and the necessity of the rites. While he immediately surmised that the rites were not lawful, in that they embodied an allegiance to the natives' religion, he did entertain the possibility that they be permitted for the sake of facilitating conversion. However, he ultimately concluded that "these signs of protest of the Eastern natives are signs that belong to their religion, and they should not be allowed in Christianity" while emphasizing the diabolical character of these practices. ${ }^{36}$ As elegant and erudite as this well-organized argument was, it showcased Figueira's mastery of the Indian milieu and was included in the Inquisition records, ${ }^{37}$ he went on to write another document, dated April 10, 1619 (copies of which were sent to

33 AntT, Conselho Geral do Santo Ofício, liv. 207, fol. $61^{\mathrm{r}}$.

34 ANTt, Conselho Geral do Santo Ofício, liv. 207, fol. $64^{\text {r }}$.

35 ANTt, Conselho Geral do Santo Ofício, liv. 207, fol. $79^{\text {r. }}$

36 Antт, Conselho Geral do Santo Ofício, liv. 207, fols. $83^{\mathrm{r}}-96^{\mathrm{r}}$.

37 Margherita Trento, "Śivadharma or Bonifacio?: Behind the Scenes of the Madurai Mission Controversy (1608-1619)," in Rites Controversies in the Early Modern World, 91-121; Giuseppe Marcocci, "Rites and Inquisition: Ethnographies of Error in Portuguese India (156o-1625)," in Rites Controversies in the Early Modern World, 145-64. 
Rome and to the General Council of the Holy Office in Lisbon). In this eightysix-page document, the prosecutor further developed the ideas he had set forth previously. ${ }^{38}$ Figueira's activism against the tolerance of the accommodation of Christian practice extended beyond textual protest. In 1620, he received a document that was prepared by five Brahmin priests, vicars of churches in Goa, who claimed that "the line and the diagram were signs of a sect." In it, the native, secular clerics explained that

the line under analysis is usually made from nine threads because the Brahmans believe that the world is divided into nine sections, and these nine threads become three thin strings that they throw to their left shoulder for them to become one. These three strings, used in worshipping their false deity, have a single knot because they say that these three false people are Brahma, Vishnu, Mtayesou; they make these nine threads to show that all the creatures from these nine parts of the world are subjected to these false gods that they worship. ${ }^{39}$

They also reported that the line was worn by the Hindu priest, the boto, and asked whether wearing the line necessarily entailed performing heathen ceremonies, or whether it was merely a sign of social distinction. Finally, they rejected the interpretations of Nobili and the archbishop of Cranganor entirely, warning of "the danger of scandal to Christendom." After this episode, in the same year, Figueira summoned several Portuguese denizens in India to appear before the Inquisition: eleven civilians, two long-time resident priests of Goa, and seven secular native clerics from several parishes and surroundings (including Bardez and Salcette). He asked the same question to all of them: "Do you know the meaning of the line?" They all answered positively, adding, without exception, that it was part of a heathen rite.

It is not difficult to perceive the prosecutor's objective: to build a solid case against Nobili's style of Christianization, warning of the potential scandal that such uses of heathen rites could bring to Christianity. ${ }^{40}$ Figueira's zeal in opposing Nobili's methods of Christianization in the Malabar region probably caused many more conflicts than those presented here. The accounts of this inquiry were sent to the inquisitor general in Lisbon, Fernão Martins de

38 Antr, Conselho Geral do Santo Ofício, liv. 474, Opinion of João Delgado Figueira, prosecutor and deputy of the Inquisition of Goa, Goa, April 10, 1619.

39 ANTt, Conselho Geral do Santo Ofício, liv. 207, fol. $98^{\text {r. }}$

40 ANTt, Conselho Geral do Santo Ofício, liv. $207,292^{\mathrm{r}}-32^{\mathrm{r}}$. 
Mascarenhas (1548-1628), as a basis for his sentence, that, he, in turn, sent to Rome; there, the matter was reviewed by three theologians, who agreed with Nobili's perspective. Based on all of these considerations, in the 1623 bull Romanae sedis antistes, Pope Gregory XV (1554-1623; r.1521-23) allowed Nobili to continue with his work, making some recommendations to avoid superstition and scandal. The bull also approved the policy of separation of castes, albeit warning against taking any action that would harm the poor and the humble.

Despite the pope's decision, the matter was not definitively settled. The biggest obstacle to its resolution lay in the reaction of the other religious orders that, in the late seventeenth century, accused the Jesuits of permitting the practice of "heathen rites." The dispute that evolved from these allegations became known as the Malabar rites affair, which came to be associated with the issue of the Chinese rites. This controversy persisted for many years, finally coming to a conclusion in the eighteenth century, when Pope Benedict XIV (1675-1758; r.1740-58), published, in 1742, the bull Ex quo singulari, denouncing certain Chinese rites as superstitious, and followed by the 1744 bull Omnium sollicitudinum, which stated the same about the Malabar rites, all in line with the opponents of the Jesuits.

During the second half of the seventeenth century, the main point of friction between the Inquisition and the Society of Jesus in the Portuguese East was the question of the newly converted Hindus. In the following pages, we will briefly show that in Portugal, the New Christians of Jewish origin stood at the center of the conflicts between both institutions. Regarding the matter of the New Christians, several incidents within the kingdom of Portugal awakened the anti-converso current, kindling popular manifestations in favor of the Inquisition and reinforcing its repressive apparatus against converso "astuteness" and "perfidy." The most serious event was the protest and prosecution unleashed against New Christians of Jewish origin after the theft of sacred vases from the church of the Monastery of Odivelas in Lisbon by an allegedly New Christian boy who, besides the theft, purportedly committed the sacrilege of damaging the altarpiece in May 1671. Although the boy himself was captured, tortured, and executed, the converso group was collectively held responsible for the incident, and became the targets of several riots incited by preachers.

Even King Pedro II (1648-1706; r.1683-1706) - under pressure from public outrage that demanded that the Holy Office adopt severe measures against all parties involved - ordered the capture of ninety wealthy New Christian merchants who lived in Lisbon or its environs, including Odivelas. Some were arrested and others were exiled to provincial cities inside the country, 
particularly the city of Guarda. Repressive measures were reinforced in line with the gravity of the event. ${ }^{41}$ The Holy Office took advantage of the situation to regain strength and prestige, especially as the population, outraged by the sacrilege, was impatient to see justice done. ${ }^{42}$ In an attempt to thwart the threat looming over the Portuguese New Christians, Manuel Gama de Pádua (1607-79), a wealthy New Christian, set off to Rome to try to secure the protection of the pope. There, he received the support of the Jesuits and in particular, the assistance of his old friend, Father António Vieira (1608-97), who had lived there in "pilgrimage" since 1669. Gama de Pádua found shared interests with the provincial of the Jesuits in the Malabar province, Baltazar Costa (1610-73), who happened to be in Rome asking for assistance for his province that had been severely damaged by the Dutch conquests in 166o. Vieira arranged a meeting between the two. Costa expressed his belief that Portugal might be able to regain the territories lost in India to France and the Netherlands.

The conversations between Gama de Pádua, Costa, and Vieira produced a proposal that served the interests of the Jesuits, the conversos, and the kingdom. In order to boost the trade between Portugal and India, Gama de Pádua proposed that the Portuguese crown should set up a commercial company with capital from the New Christians, with the earlier General Company of Commerce of Brazil as a model. In return, Rome should issue a "general pardon" to all members of the New Christian "nation." ${ }^{33}$ These negotiations involved the

41 The monarch's first, impulsive answer to appease the mutinous population was to publish the decree of July 22, 1671, which banished all conversos found guilty by the Inquisition since the last general pardon of 1605 from Portugal and ordered them sent to an auto-da-fé. This also applied to their children and grandchildren (ANTT, Armário jesuítico, maço 29, n. 13). This decree was never enforced due to its inconveniences as raised by the counsellors of King Pedro II. His Jesuit confessor also called for him to reconsider (Alexandre da Paixão, Monstruosidades do tempo e da fortuna 1662-1680, 4 vols. [Barcelos: Companhia editor do Minho, 1939], 2:122). In this work, Alexandre da Paixão expressed disapproval of Jesuit support of the New Christians, in particular that of by António Vieira. In the third volume of this book, replete with political and social considerations, Paixão expressed strong anti-Semitic views with mysterious contours, including the myth of a "Jewish" plot and the claim that the kingdom of Portugal was infected with harmful diseases caused by "the pestiferous blood of this accursed people" (Paixão, Monstruosidades do tempo e da fortuna 1662-1680, 3:50). See also João Lúcio de Azevedo, História dos Cristãos-Novos (Lisbon: Clássica, 2008), 239.

42 João Lúcio de Azevedo, História do Padre António Vieira (Lisbon: Clássica, 1992), 120; Tristão da Cunha de Ataíde, Portugal, Lisboa e a corte nos reinados de D. Pedro II e D. João V: Memórias históricas, ed. António Vasconcelos de Saldanha and Carmen M. Radulet (Lisbon: Chave Ferreira, 1990).

43 Luís de Menezes, História de Portugal restaurado, 2 vols. (Lisbon: Oficina de Miguel Deslandes, 1698), 2:468 ff. 
University of Évora, the Jesuit confessor of King Pedro II, Manuel Fernandes (1615-93), and several Portuguese prelates who came together to ask the Holy See for the "general pardon."44 Surprisingly, the king and the Holy See appeared open to a conciliatory solution. ${ }^{45}$ But in March 1673 , the Portuguese Inquisition labelled Vieira's plan heretical and treasonous. In this way, the maintenance of Portugal's religious purity trumped Portugal's recovery of India.

The supporters of the Holy Office organized demonstrations against conversos' "Judaism" and the Society of Jesus. Mobs shouted slogans against Jesuits and hung threatening messages on the doors of colleges and residences of the Society of Jesus, especially the Church of São Roque. ${ }^{46}$

Some of the demonstrations' ringleaders went further, proposing drastic solutions to the "converso problem." One such radical view came from Roque Monteiro Paim (1643-1706), who became the private secretary of King Pedro II. He wrote an anti-Semitic text, characterized by its extreme intolerance, whose title, "Jewish Perfidy," betrays its content. In this text, he advocated the expulsion of all conversos convicted as Judaizers by the Inquisition with their families, the restriction and further surveillance of the New Christian group, the prohibition of mixed marriages between New and Old Christians, and the cancellation of all privileges and honors granted to Christian descendants of Jews. Employing the timeless arguments of a "Jewish" conspiracy, he suggested that with Jesuit complicity, conversos had quickly increased their numbers in Portugal to the extent that in the near future there would not be enough Old Christians to judge them. ${ }^{47}$ As an officer of the Holy Office, he went so far as to call for purification of the "Jesuit church" by fire, claiming that it was producing heretics. He even called for the king's Jesuit confessor to be burned alive. ${ }^{48}$ This movement in favor of the Inquisition labelled Society members as "heretics," "renegades," "teachers of heretics and pagans," and "traitors," and accused them of being a dangerous "Protestant order" within the Catholic Church. ${ }^{49} \mathrm{~A}$

44 ANTt, Armário jesuítico, maço 29, n. 18.

45 Richard Graham, The Jesuit António Vieira and His Plan for the Economic Rehabilitation of Seventeenth-Century Portugal (São Paulo: Secretaria da Cultura, Ciência e Tecnologia, 1978), 179 .

46 Jayme Constantino de Freitas Moniz, ed., Corpo diplomatico portuguez, contendo os atos e relações politicas e diplomaticas de Portugal com as diversas potencias do mundo desde o século XVI até aos nossos dias, 14 vols. (Lisbon: Typ. da Academia Real das Sciencias, 1898), 14:153 ff.

47 Roque Monteiro Paim, Perfídia judaica, Christus vindex, manus principis Ecclesiae ab apostatis liberata (Madrid: n.l., 1671).

48 Graham, Jesuit António Vieira, 182.

49 Paim, Perfídia judaica, 75; Alexandre da Paixão, Monstruosidades do tempo e da fortuna (1662-1680) (Barcelos: Companhia editor do Minho, 1939), 62. 
verse from an anonymous poem then in circulation read that, with the Jesuits' support, "in less than a few days, we will all become Jews." ${ }^{50}$ Moreover, some members of the mendicant orders saw in these events a confirmation of their traditional suspicions regarding the Society of Jesus: that nothing good could ever come from them. ${ }^{51}$

Some high prelates supported the Inquisition. Among them were the bishop of Évora, who asked King Pedro II to withhold protection from the heretics and apostates, and the bishop of Leiria, who pointed out, in defense of inquisitorial repression, that when the crown had favored the New Christians, Portugal had suffered setbacks in its colonial interests, insinuating that conversos were the root of all of the kingdom's difficulties.

Despite all of the damage that the Jesuits suffered at the hands of this oppressive movement, an unfortunate but opportune event occurred that was to their advantage: the arrest and execution as "judaizers" of two nuns in Évora, who insisted on their innocence until they were executed by the Holy Office. António Vieira used this execution, which relied on the accusations of witnesses protected by inquisitorial secrecy, as proof of the unjust methods employed by the Portuguese Inquisition. In Vieira's letters, we find his criticism in full, decrying the sad situation of Portuguese society under the rule of the Holy Office. Vieira reported that this institution was reputedly known in the Italian peninsula as engaged in "killing innocent people." In a letter he wrote in Rome, he mentioned that in this capital of Catholicism, "people said that if someone was innocent, he should be sent to Portugal to be immediately burned." In other documents, Vieira described the environment of denunciations created by the inquisitional machinery within the Portuguese social framework. For example, a letter attributed to Vieira complained: "In Portugal, we cannot open or close a door without everyone knowing about it," mocking the inconsistency of the secret accusations that were used to prosecute New Christians. "When a Jew is burned, falsely accused of roasting a Paschal lamb, we can always find someone who saw him carrying the lamb in his pocket, roasting it in the fire and then swallowing the stake." 52

50 Paixão, Monstruosidades do tempo e da fortuna, 3:61-62.

51 ANTT, Armário jesuítico, maço 3o, n. 84.

52 "Letter written by Father António Vieira in Rome to a Portuguese who was also there protesting the methods of the Portuguese Inquisition" (Biblioteca da Ajuda (BA), cód. 49-IV2). See also the edition of this letter in the recent complete works of Vieira, in the section dedicated to texts of uncertain authorship: Padre António Vieira, Cartas e papéis vários, ed. Ana Lúcia M. de Oliveira and José Carlos Lopes de Miranda (Lisbon: Círculo de Leitores, 2014), 120-41. 
Vieira brought the case of the nuns to the attention of the Holy See. Clement x (1590-1676; r.1670-76) called for the inspection of the Portuguese Inquisition's proceedings, and, in 1674, he ordered the indefinite suspension of the institution..$^{53}$ A year later, the same pope granted Vieira immunity against the Portuguese Inquisition and annulled the inquisitorial sentence given against him in $1668 .{ }^{54}$ However, the Inquisition would begin to function again in less than seven years' time; in 1680, Pope Innocent XI (1611-89; r.1676-89) yielded to the pressure of the Portuguese Inquisition.

\section{Final Considerations}

In this article, we have tried to demonstrate that the main cause of friction between the Society of Jesus and the Portuguese Inquisition, beginning in the second half of the sixteenth century and continuing throughout the seventeenth century, was the issue of the "converted Christians," whether New Christians or newly converted Hindus. Despite the moments of tension in Portugal and Asia described in the article, relations between the Jesuits and the Holy Office were fairly amicable in the second half of the eighteenth century,

53 Clement X, by papal brief of October 3,1674 , reportedly favored the claims of the New Christians: he commanded the inquisitors to cease the autos-da-fé and suspend any judicial activity and reserved for himself the right to judge the cases pending before the Portuguese Inquisition. ANTt, Armário jesuítico, maço 1, n. 51; and Biblioteca Pública de Évora [BPE], cód. CX/1-1. By contrast, a committee gathered by King Pedro objected to the pope's orders, as it considered them prejudiced against the rights acquired by the Portuguese Inquisition. The influence of Father Manuel Fernandes prevented more radical measures from being taken in this extreme regarding the intrusion of the Holy See in Portuguese affairs. In any case, obedience to the papal suspension was not immediate, because the Inquisition palace gates were only effectively closed in March 1678 , in compliance with a more recent papal brief from the new pope, Innocent XI. ANTT, Armário jesuítico, maço 2, n. 304; and José Vaz de Carvalho, "António Vieira em conflito com a Inquisição," Brotéria 145 (1997): 375-91, here 389 . The Holy See had required two inquisitorial proceedings to be sent to Rome to be analyzed by the Roman Curia, an order that was repeatedly ignored. Only in 1681 did the Holy Office finally consent to send the requested proceedings to Rome. However, the pope then agreed to restore full powers to the Portuguese Inquisition on August 23 of that same year, ordering that the prisoners should be treated with kindness, that the prison should have better conditions, and that the defendants should be provided with spiritual assistance and sacraments and access to Scriptures (ANTT, Armário Jesuítico, maço 2, n. 85).

54 Through the papal brief of April 17, 1675, Pope Clement x exempted Vieira from the Portuguese Inquisition, making him answerable only to the Congregation of the Holy Office of Rome. In the same document, the pope exalted his "Catholic zeal, his knowledge of the Scriptures, his kindness and practices, as well as his other commendable qualities and actions" (António Vieira, De profecia e inquisição [Brasília: Senado Federal, 1998], 273). 
ranging from willing collaboration to a distance maintained by refraining from assuming high positions in the inquisitorial hierarchy.

In order to justify the expulsion of the Jesuits from Portugal in 1759 and reform the Inquisition, the state propaganda led by Sebastião José de Carvalho e Melo, Marquis of Pombal (1699-1782), closely linked the Society of Jesus to the Holy Office. Particularly, the Pombaline statutes, which sought to reform the Holy Office in light of political criteria based on Enlightenment absolutism, supported the incorporation of this institution within the state apparatus by claiming that it had been instrumentalized as a result of the "nefarious" influence of the Society of Jesus. The allegation of the existence of a hidden connection between inquisitors and Jesuits was more a propaganda tool deployed in service of Pombal's political interests than a reflection of the more complex history of the relationship between the Portuguese Inquisition and the Jesuits.

Jesuits played a supportive role in the activities of the Inquisition and in the consolidation of this institution in Portugal, as did the other orders and members of the clergy. As we argued in this article, the Holy Office established itself as a consensual institution within Portuguese society. Since its foundation, the Society of Jesus could not come to a consensus on the issue of participation in the institutional hierarchy of the Inquisition. However, despite the precautions taken by the founder of the Jesuits regarding non-participation in the ranks of the Holy Office, which were reinforced by other Jesuit superiors general who succeeded him, many members of the Society of Jesus were ultimately drafted to that tribunal as qualifiers, advisors, preachers, or visitors, whether as a matter of obligation or because they were convinced to cooperate with an institution that purportedly safeguarded the faith.

In any case, the documentation available today allows us to see an increasing outcry by Society members against the activities of the Inquisition, urging moderation and reform, particularly during the seventeenth century. These critical voices not only arose from doubts regarding the evangelical nature of the Holy Office, but also stemmed from a Jesuit connection with the New Christian group in light of common interests related to the kingdom of Portugal. In addition, such reservations emanated from the theological conclusions of several prominent Jesuits who questioned certain institutions and doctrinal notions, as we have shown in the case of the Malabar rites. In short, the relationship between Jesuits and conversos, as it pertains to the questions of the newly converted Christians in India and the Inquisition during the sixteenth and seventeenth centuries, must be analyzed in light of a society simultaneously controlled by the state and influenced by the church, in which a great diversity of religious orders cooperated, competed, and collided. 